\title{
Business Model Innovation and Micro and Small Enterprises' Performance in Nigeria: Does Entrepreneurial Orientation Mediate?
}

\author{
Dotun Olaleye Faloye \\ $\mathrm{PhD}$, Department of Business Administration Adekunle Ajasin University \\ Idowu Owoeye \\ $\mathrm{PhD}$, Department of Business Administration Adekunle Ajasin University
}

\section{Abstract}

The critical role of business model innovation (BMI) in a firm's performance has earned increasing attention from scholars and management practitioners in recent years. However, empirical research on how BMI linked business performance is quite skimpy. This study examines the effect of BMI on micro and small enterprises (MSEs) and how entrepreneurship orientation (EO) mediates the relationship. A survey research design is used in this study. Data were obtained from 142 MSEs operating in Ondo State, Nigeria, purposively selected for this study. The results revealed that BMI $(\beta=0.630 ; \rho<0.01)$ had a positive and significant influence on the MSEs' performance. More so, this study found that EO $(\beta=0.716 ; \rho<0.01)$ is positively related to a firm's performance. This study finding revealed a positive and significant link between EO and BMI $(\beta=0.838 ; \rho=0.000)$. Also, this study showed that EO mediates the relationship between BMI and a firm's performance (EO: $\beta=$ 0.5740 ; BMI: $\beta=0.1281 ; \rho<0.05)$. Statistically, the study's findings also exhibited that out of the six constructs used to capture BMI, only two constructs, namely, market opportunities $(\beta=0.193 ; \rho<0.01)$ and increment in revenue generation $((\beta=0.230 ; \rho<0.01)$, had positive and significant links with the firm's performance. This study concluded that MSEs in developing economies, especially in sub-Saharan African countries, should integrate BMI and $\mathrm{EO}$ activities into their operations to overcome the macerate performance that characterized the Covid 19 pandemic period.

Keywords: business model innovation, entrepreneurship orientation, firm's performance, micro and small business, Nigeria 


\section{Introduction}

The importance of Micro, Small, and Medium Scale Enterprises (MSMEs) in economic growth all over the world cannot be over-emphasized. MSMEs' roles had been widely researched in both developed and developing countries (Tambunan, 2019; Kurniawati \& Setiawan, 2019; Madanchian et al., 2016). MSMEs have been playing a vital role worldwide in national economies, value-added, and employment generation. Approximately MSMEs are accounting for $99 \%$ of all firms and about $70 \%$ of total employment. In terms of value creation, MSMEs, on average, are generating between $50 \%$ and $60 \%$ of value-added (OECD, 2016; IFC, 2010).

The contributions of SMEs to the world economic growth generally, particularly in developing countries, in terms of employment generation and gross domestic product (GDP) have been reported across countries. For example, in the United States of America, SMEs generate $44 \%$ of total economic activity, and in recent decades, SMEs account for about nearly $66.7 \%$ of net new private-sector jobs. Also, SMEs account for 99.9\% of all United States of America businesses and employment share of $47.5 \%$ as of the year 2019. Also, in the United Kingdom, at the start of 2019, 99.9\% of the business population is accounting for by SMEs; besides, SMEs account for $60 \%$ of the employment, and SMEs turnover was estimated at 52\%. In the case of China, SMEs generate over $82 \%$ of employment opportunities, while SMEs' output value accounts for at least $60 \%$ of the country's gross domestic product (GDP) and makes up over $99 \%$ of all enterprises in the country. The statistics show that SMEs constitute about $99 \%$ of all enterprises while employing $90 \%$ of the Non-Agricultural workforce and contribute 30\% of the country's GDP. In 2018, Malaysia's MSMEs contributed 38.3\% to the country's GDP, constituted $98.5 \%$ of all businesses establishments, and provided about 5.7 million jobs ( $70 \%$ of the workforce in Malaysia). Indonesia MSMEs accounted for approximately $61.41 \%$ of GDP, while total employment generated was around $99 \%$ and constituted $99.8 \%$ of the total business generated. In Brazil, SMEs contribute $27 \%$ of national GDP, account for $98.5 \%$ of businesses, and $62 \%$ of total employment. The statistics are not different in some of the African countries. For instance, in Nigeria and South Africa, SMEs in both countries account for $96 \%$ and $91 \%$ of businesses while contributing $48 \%$ and $52 \%$ of total GDP and $84 \%$ and $60 \%$ of employment. In Ghana, the second-largest economy in West Africa, SMEs provide about $85 \%$ of manufacturing employment, contribute about $70 \%$ to the nation's GDP, and account for about 92\% of businesses in Ghana (FSB, 2020; ICSB, 2019; SBA, 2019; Tambunan, 2019; China Statistical Yearbook, 2019; Department of Statistics Malaysia (DOSM), 2018; Zafar \& Mustafa, 2017).

Despite the laudable contributions of MSMEs to the growth and development of the world economy, they are still facing many challenges that are inhibiting their development. Many scholars and management practitioners (Raghuvanshi et al., 2017; Wang, 2017; Santos \& Moustafa, 2016; Gherhes, et al., 2016; Yoshino \& Taghizadeh-Hesary, 2016; Nassar \& Faloye, 2015; Faloye, 2015; Tambunan, 2018; 
Oyelana \& Adu, 2015; Quartey, 2015) have identified several factors that constrained the development of SMEs in developed, emerging and developing countries. Some of these problems are; limited access to international markets, limited access to finance, lack of databases, low R\&D expenditure, inconsistencies of government policy, unfair competition, multiple taxes, and unauthorized levies, tendency to be growth-averse, and underdeveloped capabilities.

In order to position developing countries' MSMEs in overcoming challenges facing them and fostering economic development, many interventions had been proposed in literature notable among these are internationalization, innovation, adoption of $\mathrm{E}$ commerce, proactiveness, risk-taking, and autonomy orientations (Steinhäuser et al., 2020; Stoian et al., 2018; Saeed \& Alrawashedh, 2018; OECD, 2018; Rahayu \& Day, 2017; Terjesen et al., 2016; Faloye, 2014). However, very recently, both academics and management practitioners have shifted focus towards innovation generally and business model innovation (BMI) specifically to enhance MSMEs' performance. Kyllianen (2019) defined BMI "as a fundamental change in how a company delivers value to its customers or captures it from the market."

The influence of BMI on the firm performance has attracted more and more attention (Foss \& Saebi, 2017; Bouncken \& Fredrich, 2016), notwithstanding, there has not been a consensus among the BMI scholars on the empirical relationship between BMI and firm's performance. Some studies showed that there is negative relationship, some revealed positive while in some instances, no significant relationship were reported (Desyllas et al., 2020; Asemokha et al., 2019; Bustinza et al., 2019; Clauss et al., 2019; Tavassoli \& Bengtsson, 2018; Latifi \& Bouwman, 2018; Karimi \& Walter, 2016). Despite the link reported in the literature between BMI and organizational performance, there is still ambiguity on how BMI results in organizational performance (Latifi \& Bouwman, 2018). Evidence from the literature showed that BMI does not automatically trigger impressive performance gain (Haggège et al., 2017). For instance, it is widely believed that BMI can create a competitive advantage, which in turn enhances performance (Karimi \& Walter, 2016). Also, leadership style, top management support, organizational culture, customer focus, process control; employee orientation, entrepreneurship orientation, and technological orientation have been identified as mediators between BMI and organizational performance (Gupta \& Batra, 2015; Tsai \& Yang, 2013; Awan, 2013). Thus, the processes in which BMI influences performance have not been established in the literature (Knab \& Rohrbeck, 2014). Hence, the causal relationship between BMI activities and performance is still puzzling.

According to Knab and Rohrbeck (2014) cited in Latifi and Bouwman (2018), business owners would be more effective when they have adequate knowledge of how BMI influences a firm's performance. Entrepreneurial orientation had been suggested by scholars (Kiyabo \& Isaga, 2020; Asemokha et al., 2019; Dewi \& Ahamat, 2018) as a critical factor that mediates the relationship between BMI and firm's 
performance mostly in MSEs. However, despite the importance of entrepreneurial orientation as expressed in the resource-based view, the mediating effect of entrepreneurial orientation on the relationship between BMI and firm performance is not yet extensively studied generally in developing countries' MSEs, and particularly in sub-Saharan African's MSEs (Mahmood \& Hanafi, 2013). The holistic review of the literature showed that the majority of the existing studies on the processes in which BMI influences organizational performance were qualitative and concentrated in the developed countries; only a few of these studies are empirical and focused on developing economies, specifically sub-Saharan African countries. This study is an answer to calls by many researchers (Faloye et al., 2021; Latifi \& Bouwman, 2018; Haggège et al., 2017; Spieth et al., 2016; Clauss, 2016) for empirical studies on how BMI interventions lead to firm's performance. Therefore, this paper was designed to explore the link between BMI and small business performance. More so, this paper examined how the relationship between BMI and small business performance is mediated by entrepreneurship orientation using Nigerian micro and small business enterprises. The rest of the paper is structured as follows. The following section discusses the theoretical foundations, develops the hypotheses, and presents the research model. The subsequent sections present the research methodology, data analysis, and results. Lastly, the paper concludes with a discussion of the research findings, the implications for theory and practice, and the limitations of the paper and suggests avenues for future research.

\section{Literature Review}

\subsection{Conceptual Review}

\section{Business Model Innovation}

Snihur and Zott (2020) conceptualized BMI as "the introduction of a business model that is novel (in terms of its content, structure, or governance) to the product market space in which the venture competes." According to Amit and Zott (2001), cited in Snihur and Zott (2020), BMI consists of three core elements: content, structure, and governance. According to them, content has to do with the alternative activities that are accomplished within the system. While the structure is captured as how activities are connected and governance refers to issues of control. Casadesus-Masanell and Zhu (2013), cited in Laszczuk and Mayer (2020), sees BMI as "the search for new logics of the firm and new ways to create and capture value for its stakeholders." This means that BMI is far beyond process and product innovation and entails redesigning an organization's operations and activities (Bjorkdahl \& Holmén, 2013). Bhatti et al. (2020) viewed BMI "as a continuum of changes from incremental to radical changes in various business model factors." In the study conducted by Baghiu (2020), BMI was described as an avenue to flare up from intense competitors in a situation in which a company's offering can be easily imitated. Also, Geissdoerfer et al. (2018) analyzed various definitions of BMI in literature. Based on this analysis, they defined business model innovation "as the conceptualization and implementation of new business 
models. This can comprise the development of entirely new business models, the diversification into additional business models, the acquisition of new business models, or the transformation from one business model to another". The transformation can impact the whole business model or a subset or a combination of its value proposition, value creation, and delivery, and value capture elements, the interrelations between the elements, and the value network. This definition given by Geissdoerfer et al. (2018) is more detailed when compared with definitions given by previous authors.

\section{Entrepreneurship Orientation}

The concept of Entrepreneurship Orientation (EO) was initially introduced into the scholarly conversation as an organizational attribute when it was observed that, as individuals, organizations could "be entrepreneurial" (Covin \& Wales, 2019). EO had been described as is a significant contributor to a firm's success, and the concept was developed by Miller (1983). Miller (2011) sees EO as the process of formation of corporate strategy while Wales (2015) expressed EO "as a strategic posture of the organization that exhibits innovativeness, proactiveness, and risk-taking, as a whole or uni-dimensional." What constitutes the EO construct has been a subject of debate in the literature in the past. More so, Anderson et al. (2015) view EO as "a firm's strategic posture towards entrepreneurship." According to Zulkifli and Rosli (2013), three dimensions, namely, risk-taking, innovativeness, and proactiveness, were used in earlier studies to capture entrepreneurship orientation. These three dimensions were considered as the best-defining features of the concept of entrepreneurial orientation (Lomberg et al., 2017). Later the scope of the EO construct was expanded to include two more dimensions, namely, autonomy and competitive aggressiveness (Campos \& Valenzuela, 2013; Zehir et al., 2015). Risk-taking involves carrying out actions that involve resources commitment with uncertainty regarding the potential profits (Rigtering et al., 2017). Proactiveness, on the other hand, involves taking action before any competitors (Anderson et al., 2015). In contrast, innovativeness has to do with a creative process that supports new ideas (Covin et al., 2016), autonomy refers to the independence of an individual or team of individuals within an organization to develop an entrepreneurial idea and then see it through to completion (Wikipedia, 2014). Competitive aggressiveness can be expressed as the tendency to intensely and directly challenge competitors rather than trying to avoid them (Maloney, 2014). In this study, to analyze the direct effects of entrepreneurial orientation on firm performance, we considered EO as multidimensional, integrating innovativeness, proactiveness, risk-taking, autonomy, and competitive aggressiveness (Hernández-Perlines et al., 2016).

\section{Firm Performance}

Performance has been seen as an essential concept in management research. It has always been at the core of management thinking since it has been perceived to directly link with the sustainability of firms (Haggège et al., 2017; Rauter et al., 2017). 
The organizational performance reveals a picture of the organization's progress and how well it is attaining its goals (Choudhary et al., 2013). Also, Almatrooshi et al. (2016) opined that organizational performance is an essential consideration for a firm as it can be a driver of organizational success. The firm performance was used in financial performance, customer performance, internal business process performance, and learning and growth performance (Lyu et al., 2018; Lin \& Tseng, 2016). According to Dekker et al. (2015), cited in Sriviboon (2020), researchers have developed series of financial indicators for measuring firm performance these include; return on net assets, profit growth rate, the net growth rate of total assets, shareholder return, growth in market share, return on sales, return on capital and number of new products. A firm's performance construct can be unidimensional or multidimensional (Selvam et al. (2016). Researchers have given different models of a firm's performance. However, it had been argued that a multidimensional perspective that consists of financial and non-financial dimensions must be employed to measure a firm performance (Dekker et al., 2015). The non-financial dimensions include; client satisfaction, employee satisfaction, innovation ability, internal business process proficiency, efficiency, market share, productivity, behavioral and attitudinal measures, while in case of economic dimensions, these measures include net profit, sales, return on sales, gross profit, return on equity, return on investment, and return on assets (Dekker et al., 2015; Selvam et al., 2016; Almatrooshi et al., 2016; AbdelMaksoud et al.,2016). Selvam et al. (2016) gave the most comprehensive model for measuring a firm's performance based on the review of the existing literature on the firm's performance. According to them, profitability, growth, market value, customers' satisfaction, employees' satisfaction, environmental performance, environmental audit performance, corporate governance performance, and social performance are key constructs of a firm's performance. Organizational performance is influenced by several dependencies such as employee performance, goal attainment, and leadership capability in influence, problem-solving, and mentoring.

\section{Micro and Small Scale Enterprises in Nigeria Context}

Academics and management practitioners had made several attempts to conceptualized micro and small-scale enterprises. There is yet to be unanimity on the definition of MSEs in developed, emerging, and developing countries. What constitutes MSEs varies from country to country. The story is not different in Nigeria. Various definitions of MSEs were given by Scholars, government agencies, and management practitioners. However, the classification given by the Small and Medium Enterprises Development Agency of Nigeria (SMEDAN) in 2007 is widely accepted as a working definition by many scholars in the country (Faloye \& Nassar, 2015), thus, this study adopted this definition. The classification is employment and assets based. The agency classified businesses that employ less than ten employees and have less than five million Naira (N5,000,000) (excluding land and building) as Micro enterprises. In contrast, businesses engaged between ten and forty-nine employees and capital between five million and fifty million naira (N5,000,000 to 
N50,000,000) excluding land and buildings as small enterprises. According to the National Policy document, where there is dissension in classification between employment and assets criteria, the employment-based classification will prevail over assets-based criteria.

\subsection{Theoretical Framework}

\section{Resource-Based View Theory}

Resource-based view theory (RBV), as further developed by Barney (1991), emphasized the need for a firm to leverage its internal resources and capabilities to create a competitive advantage. As posited by Barney (1991), the competitive advantage sought by a firm must be sustainable, and therefore the sustainability remains a function of designed and developed resources and capabilities that are valuable, uncommon, inimitable, and non-substitutable. The resources possessed by an organization are termed inputs that are harnessed, processed and converted to create values addition. According to Gupta et al. (2007), the resources at the disposal of an organization to create competitive advantage may constitute physical, human, organizational, and intangible assets, and therefore the deployment of these resources to attain organizational goals can be explained in term of organizational capability. While a handful of studies have borrowed from the theoretical lens of RBV to buoy evidence that performance earned in an organization was as a result of the organization's resources that are largely valuable, intimidated, uncommon, and nonsubstitutable (Salisu \& Bakar, 2019; Ringim et al., 2017), however, it has been argued that these resources and capabilities can be copied and substituted. As remarked by Gupta, et al. (2007), if resources and capabilities can be imitated and even substituted, a firm can develop and build its capabilities to create a value addition leading to sustainable advantage. That is, a firm can build and deploy its resources for creating value addition that cannot be copied and difficult by competitors in the market. In literature, BMI has been identified to have the capability to yield higher returns and to invoke dynamic competitive advantage (Casadesus-Masanell \& Zhu, 2013; Lindgardt \& Reeves, 2015). Therefore, it (BMI) can be developed and built as internal capabilities to create values that competitors find uncommon, difficult to imitate and be substituted. Despite using RBV in research studies, drawing insights to underpin studies on BMI and performance-related outcomes have remained limited and anecdotal in research undertakings. This study hinged on the theoretical lens of RBV to anchor the relationship between BMI and performance-related outcomes using EO as a mediating mechanism.

\subsection{Empirical Review and Hypothesis Development}

\section{BMI and Firm's Performance}

Researchers have attempted to probe the impact of BMI on firm performance in developed and developing countries. There is a discrepancy in the literature on the influence of BMI on business performance. Some studies reported a positive link 
between BMI and firm performance, while some researches also established negative relationships. Besides, few of the existing studies revealed that there were zero relationships between BMI and organizational performance. For instance, Desyllas et al. (2020) conducted a study on the breadth of business model configuration and firm performance using data from an original survey of knowledge-intensive business services firms. The analysis of the data collected for the study revealed that the influence of business model reconfiguration on firm performance was minimal. Another laudable contribution was made by Asemokha et al. (2019). The researchers used a cross-industrial sample of 95 Finnish international SMEs, and the study findings showed that BMI is an important driver of firm performance. A study focusing on the "Strategic Agility, Business Model Innovation and Firm Performance: An Empirical Investigation" was conducted by Clauss et al. (2019). The research investigated the mediating role played by BMI on the link between firm-level strategic agility and firm performance using data from 432 German firms in the electronics industry. Finding from the study revealed that value proposition and value creation BMIs have positive relationships with firm performance.

Furthermore, Pucihar et al. (2019) carried out a study to investigate the drivers and outcomes of BMI in SMEs. They employed a partial least squares path modelling to empirically test the study model by utilizing the data collected from 71 SMEs in Slovenia. The study findings showed that BMI has a positive and significant influence on both BMI outcomes and business performance. More so, in a study that analysed the relationship between technological innovation and business model innovations and their effect on business performance, Smajlović et al. (2019) employed Structural Equation Modelling to analyze the data collected on medium and large enterprises in a Southeast European developing country. Their study findings revealed a significant and positive link between technological innovation and business model innovation; besides, the study showed that BMI was positively related to business performance. The influence of BMI on organization performance was also examined empirically by Dewi and Ahamat (2018). The Duo examined the influence of BMI on organizational performance using 105 private hospitals in Indonesia as a case study. According to them, BMI mediates the significant positive relationship between entrepreneurial orientation and firm performance. More so, in a study focusing on digitalization and business model using 338 European SMEs, Bouwman et al. (2018) established that BMI positively influences business performance. In the study conducted by Tavassoli and Bengtsson (2018) on the effect of business model innovation (BMI) on the product innovation performance of firms in which a large-scale representative sample of cross-industry Swedish firms was used as study respondents. The Duo revealed that there was a significant and positive relationship between BMI and product innovation performance. A similar result was found in the work of Heij et al. (2017) titled "how does business model innovation influence firm performance? the effect of environmental dynamism". Large scale survey was employed in the study, and the data analysis results indicated that business model replication and business 
model renewal positively and significantly affect firm performance. Cucculelli and Bettinelli (2015) researched the association of BMI with firm performance in 376 Italian small and medium enterprises using the clothing sector over the period 20002010. Their study showed that BMI is related positively to firm performance. Therefore, in light of the above findings, we propose the following hypothesis:

$H_{1}$ : Business model innovation has a significant positive impact on small business performance

\section{Entrepreneurship Orientation and Business Model Innovation}

The link between Business Model Innovation (BMI) and Entrepreneurial Orientation (EO) and their role in business performance have been increasingly emphasized in academic research. Although there are limited empirical studies on the topic, there are seems to be a consensus among the scholars on the relationship between BMI and EO on the one hand and the role played by BMI and EO on firm performance. For instance, Bouncken et al. (2016) examined the role of EO in business model innovation using service companies. The study findings showed that EO triggered and favored BMI. Furthermore, in a work carried out byRakesh Kumar Pati (2018) titled 'Missing link between entrepreneurial orientation and firm performance: Business model innovation.' 197 Indian SMEs were sampled. This study showed a significant favorable influence between BMI and three dimensions of EO: proactiveness, innovativeness, and risk-taking. More so, according to Danarahmanto et al. (2019), "Entrepreneurial orientation and innovation are required to support the business model." This study exhibited that there is a link between EO and BMI.

Similarly, Lianfeng et al. (2021) opined that the effect of entrepreneurship orientation on business model innovation was positively significant and BMI moderate the relationship between EO and economic performance. Asemokha et al. (2019) conducted a study exploring the indirect role of BMI in the relationship between entrepreneurial orientation and international performance among internationalizing SMEs. The results revealed that BMI mediates positively and significantly the link between EO and the international performance of SMEs. More so, EO positively and significantly influence BMI in SMEs. Also, Mütterlein and Kunz (2017), in a study titled "Innovate alone or with others? Influence of entrepreneurial orientation and alliance orientation on media business model innovation,". A quantitative survey of 50 companies was used for the study, and results showed that entrepreneurial orientation positively and significantly impacts the ability to innovate value creation and value proposition. In recent research conducted by Ciampi et al. (2021) using survey data from $253 \mathrm{UK}$ firms, EO mediated the relationship between the Big Data Analytics Capabilities and BMI. Also, the mediating role of BMI on the relationship between $\mathrm{EO}$ and business performance has been investigated by academic scholars. Existing literature had shown that BMI plays an indirect role in the link between EO and organizational performance. For instance, Dawi and Ahamat (2018) conducted a study investigating the impact of entrepreneurial orientation on firm performance 
through the mediation of business model innovation. One hundred five private hospitals in Indonesia were used as the study sample. The study findings established that the entrepreneurial orientation of the hospital has a significant favorable influence on the attainment of organizational performance through the mediation role of business model innovation. Similarly, Aunalal and Aponno (2019) surveyed 299 units of SMEs in Ambon city to examine innovation as an intervening variable on the entrepreneurial orientation and learning orientation towards the SMEs' performance. The result showed that innovation mediated the effect of entrepreneurial orientation on firm performance. Therefore, the study second hypothesis shall be formulated as follows:

$H_{2 a}:$ Entrepreneurial orientation mediate the relationship between business model innovation and small business performance

$H_{2 b}$ : Entrepreneurial orientation positively and significantly influence business model innovation

\section{Entrepreneurship Orientation and Firm's Performance}

Studies from both developed and developing countries had investigated the relationship between entrepreneurial orientation and business performance, and their findings have shown a positive link between the two variables. For instance, in a research conducted by Filser and Eggers (2013), the impact of entrepreneurship orientation constructs, namely; Innovativeness, proactiveness, and risk-taking, on SMEs' performance Rhine Vally using 304 business owners were examined. The Duo established that innovativeness and risk-taking positively influence the performance of SMEs. However, proactiveness did not affect SMEs' performance. A recent study by Cuevas-Vargas et al. (2019) investigates entrepreneurship's direct and indirect influence; however, (EO) on small businesses' performance. The partial least square structural equation modeling results revealed that entrepreneurial orientation positively and significantly impacts business and customer satisfaction. Also, Soares and Perin (2020) opined that the relationship between EO and firm performance was direct and positive. More so, Dawi and Ahamat (2018), using 105 private hospitals in Indonesia, examined the role of entrepreneurial orientation in attaining the firm's best performance. They found that the entrepreneurial orientation of the selected firm significantly and positively influenced business performance. The works of Huang et al. (2012), Kim and Min (2015), Bouncken and Fredrich (2016), and Foss and Saebi (2017) also indicated a positive relationship between EO and firm performance. The work of Dewi and Ahamat (2018) was carried out in 105 private hospitals in Indonesia. The data collected for the study were analyzed using the Structural Equation Modelling program. The study findings revealed that the entrepreneurial orientation of the selected firm has a positive and significant influence on the attainment of organizational performance. However, researchers such as Lonial and Carter (2015) found no significant and positive link between EO 
and organizational performance. Therefore, in this study, we proposed the following hypothesis:

\section{$H_{3}:$ Entrepreneurial orientation positively influences a firm's performance}

\subsection{Conceptual Framework}

The conceptual framework shows the empirical relationship between the study's Dependent, Mediating, and Independent variables. The excess of the conceptual framework is to describe concepts relevant to the study and map relationships among them. In this study, both BMI and EO played independent and mediating variables while firm performance was a dependent variable. It has been established in the literature that there is a direct and indirect relationship between BMI, EO, and firm performance. The diagram below shows the study model.

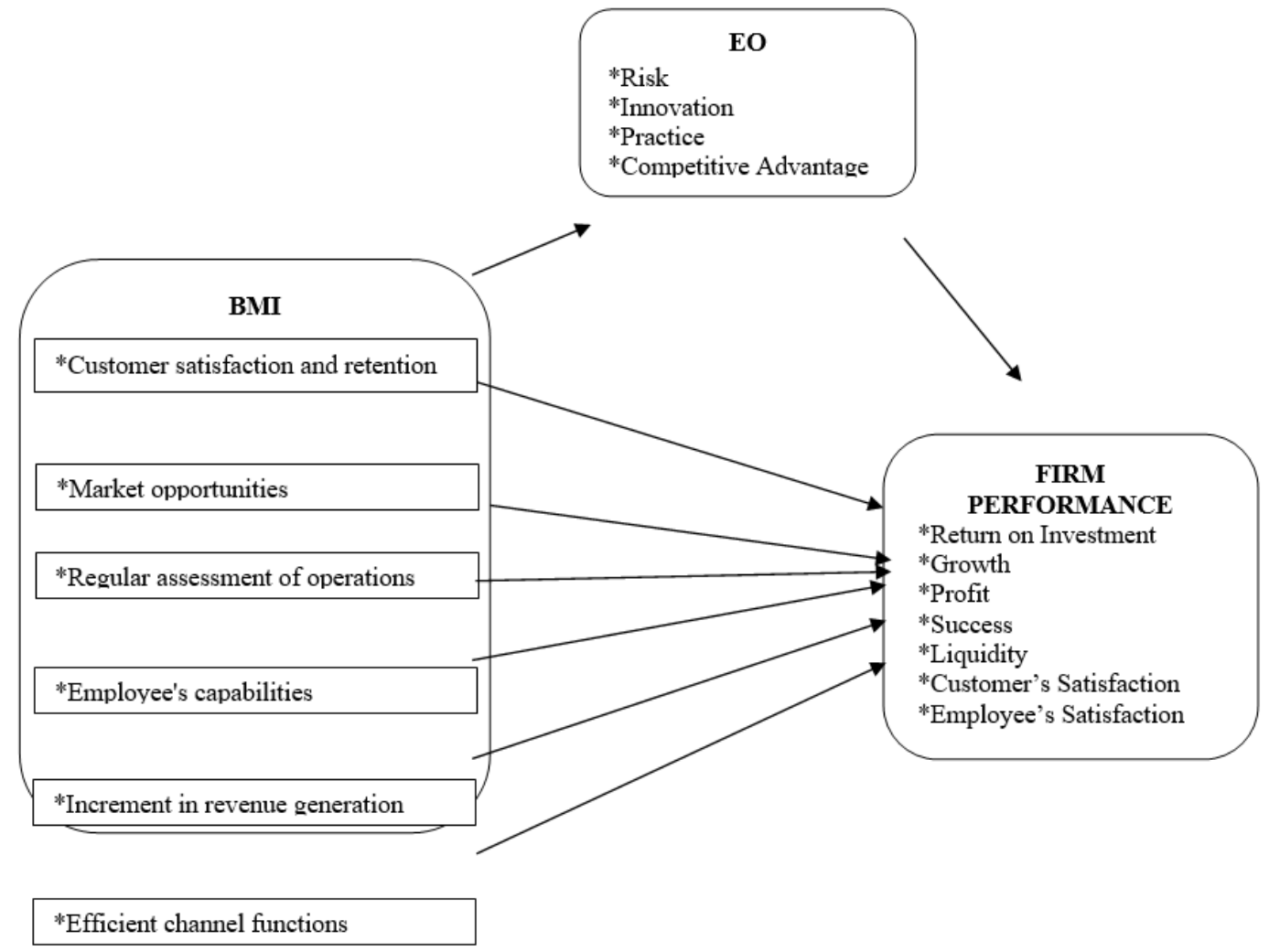

Source: Authors' Design 2021

\section{Research method}

The research was conducted in Ondo state, Southwest Nigeria. The selected state for the study is divided into three (3) Senatorial Districts, and each district comprises six (6) local government areas. Nine (9) major commercial towns that house almost 90 
percent of small businesses (Fatusin, 2012) within the three (3) senatorial districts were selected for this study. Survey research was adopted for the study. Data used for the study were obtained through primary sources, and questionnaires were used to collect the data from the selected small business owners/representatives. All small businesses (registered and unregistered) operating within the selected study locations constitute this study population. The researchers included informal small businesses because they formed the bulk of the small businesses in the sample areas. Since the study population could not be ascertained, purposive sampling techniques were employed in selecting the respondents for the study. The researchers purposively selected 450 small business owners/representatives, and questionnaires were administered to them between October and December 2020. Out of the 450 questionnaires distributed, 142 (31.56\%) questionnaires were duly completed and returned by the selected small business owners/representatives.

Despite that the response rate was low due to the Covid 19 pandemic, the researchers believed that it was representative enough to generalize the research findings. Questionnaires developed by Hughes and Morgan (2007) and Campos et al. (2012) on EO were adapted for the study with Cronbach's alpha of 0.70. Also, the questionnaire designed by Shepherd and Wiklund (2009) measuring performance was adapted, while the questionnaire constructed by Clauß (2017) on BMI determinants was adapted for the study. The questionnaire used to capture BMI was initially structured into ten sub-constructs and contained 31 items by Clauß (2017). However, Faloye et al. (2021) restructured it into six constructs: customer satisfaction and retention, market opportunities, regular assessment of operations, employee capabilities, increment in revenue generation, and efficient channel functions, with 27 items and reported Cronbach's Alpha of 0.957. These research instruments were considered appropriate for the study because the previous study shows consistent pictures of what they measured. For instance, the Cronbach's Alpha for Clauß (2017), Hughes and Morgan (2007), Campos et al. (2012), and Shepherd and Wiklund (2009) questionnaires ranges between 0.70 and 0.89 for all items. Both descriptive and inferential statistical tools were employed in analyzing the data obtained for the study using SPSS 23.0 Version software. In order to ascertain the effect of entrepreneurial orientation, PROCESS MACRO software developed by Hayes (2018) was employed in this study. PROCESS MACRO has the capacity to compress the steps involve in determining the mediation effect when using hierarchical regression statistics.

\section{Results and Discussion of Findings}

\subsection{Profile of the selected Micro and Small Businesses}

The data collected on the biodata of the respondents for this study showed that there were more males than females who were either owners/representatives or managers in the sampled micro and small businesses in the selected areas. Out of the 142 small businesses sampled, 52.1 percent were male, while 47.9 were female. In terms of the 
age of the study respondents, the majority (63.8\%) were within the age bracket between 30 and 49 years. Respondents that were 50 years and above were 36.2 percent. The level of education and literacy among the MSEs owners/managers in the selected areas were very high. Out of 142 MSEs sampled, 66.2 percent of owners/representatives claimed to have attended tertiary institutions. The proportion of those with only high school education was 21.1 percent. However, the proportion of SMEs' owners/managers with postgraduate education was only 12.7 percent of the total respondents. Also, 43.7 percent of the selected MSEs had been in existence for less than six years, followed by 23.9 percent that had been in existence between 6 and 10 years. Those MSEs that had their existence above 16 years constituted just 12.7 percent. This showed that only a few of the Nigerian small businesses have a life span above 16 years. In summary, most of the study respondents were male, educated, and had been in existence for less than six years.

\subsection{Reliability Test}

The reliability of the research instruments was tested using Cronbach's Alpha. The instrument used to measure BMI, entrepreneurship orientation, and firm's performance contained 27, 19, and 20 items, respectively. Table 1 showed that the Cronbach's alpha for the research instruments used in this study was above 0.9 , which was considered very high, and this showed that the research instruments were reliable and consistent.

Table 1: Reliability Test of the research instrument

\begin{tabular}{|l|l|l|l|}
\hline S/N & Variable & Number of Items & Cronbach's Alpha \\
\hline 1 & Business Model Innovation & 27 & 0.957 \\
\hline 2 & Entrepreneurship Orientation & 19 & 0.948 \\
\hline 3 & Firm Performance & 20 & 0.923 \\
\hline
\end{tabular}

Source: Data Analysis, 2021

\subsection{Correlation and Regression Analysis Results}

Correlation analysis and multiple regression analysis were performed on the data collected for this study. The results were compressed in Tables 2, 3, 4, and 5. The Pearson correlation and regression analysis results in Table 2 revealed the relationship between each of the BMI constructs and the firm's performance in the selected small businesses. The significant correlation results (** Correlation is significant at the 0.01) showed that all the constructs of BMI (customer satisfaction and retention, market opportunities, regular assessment of operations, employee's capabilities, increment in revenue generation, and efficient channel functions) had a significant relationship with firm's performance $(\rho<0.01)$. However, only customer satisfaction and retention $(r=0.627)$, market opportunities $(r=0.614)$, and increment in revenue generation $(\mathrm{r}=0.645)$ displayed strong positive significant 
relationship with firm's performance. Regular assessment of operations ( $\mathrm{r}=0.582)$ and efficient channel functions $(r=0.596)$ constructs had a moderate positive significant relationship with the firm's performance while regular assessment of operations $(r=0.496)$ construct showed a weak positive but significant link with firm's performance. Table 2 also displayed the results of the multiple regression test. The firm's performance was used as the dependent variable in the model, while the independent variables were the six constructs of BMI. The possibility of multicollinearity in the study is ruled out as the BMI constructs have correlation values below 0.80 (Jalali et al.,2014).

The regression results displayed in Table 2 consist of the total variance explained (R2 and adjusted R2 Score), the F-test (ANOVA), which determines whether the model is valid, and the regression of the complete model, including the coefficients and the significance of each of the variables. The value of the R2 in this model was 0.547 . This means that the model explained 54.7 percent of the variance in the dependent variable. The value of the adjusted $\mathrm{R} 2$ was 0.527 . This showed that the model explained 52.7 percent of the variation in a firm's performance, and the model was significant $(\mathrm{F}=27.144 ; \rho$-value $=0.000)$. Also, Table 2 shows the outcome of an ANOVA test. The F-value and its significance indicated that the model was very significant. Stated otherwise, the chance that the model is not usable is less than 0.000 . Finally, Table 2 showed the complete model of the regression. The coefficients of the variables and their significance were shown. The coefficients of all the variables (Standardized estimate $\beta$ ) were positive, but only market opportunities and increment in revenue generation were significant $(\rho<0.01)$ at 1 percent. These results imply that only market opportunities (external factor) and increment in revenue generation (internal factor) had a significant positive relationship with the firm's performance in the sampled small businesses in Nigeria. This contradicts the finding by Pucihar et al. (2019) that the innovativeness of enterprises and their business environment had a significant positive effect on the level of BMI activities in the firms. However, this research finding agrees with Martinez et al. (2021) that BMI in small enterprises during the Covid 19 pandemic is influenced by internal and external factors. 
Table 2: Regression Analysis Results on the Effect of BMI Dimensions on Firm's Performance

\begin{tabular}{|c|c|c|c|c|c|c|c|c|}
\hline \multicolumn{9}{|c|}{ MODEL SUMMARY } \\
\hline Model & $\mathrm{R}$ & \multirow{2}{*}{$\begin{array}{l}\text { R Square } \\
0.547\end{array}$} & \multirow{2}{*}{\multicolumn{3}{|c|}{ Adjusted R Square }} & \multirow{2}{*}{$\begin{array}{l}\mathrm{F} \\
27.144\end{array}$} & \multirow{2}{*}{$\begin{array}{l}\text { Sig. } \\
0.000\end{array}$} & \multirow{2}{*}{$\begin{array}{c}\text { Durbin-Watson } \\
1.870 \\
\end{array}$} \\
\hline 1 & 0.739 & & & & & & & \\
\hline \multicolumn{9}{|l|}{$\overline{\text { ANOVA }}$} \\
\hline Model & Sum of Squares & df & Mean Square & & $\mathrm{F}$ & & Sig. & \\
\hline Regression & 54.808 & 6 & 9.135 & & 27. & 144 & 0.000 & \\
\hline Residual & 45.431 & 135 & 0.337 & & & & & \\
\hline Total & 100.239 & 141 & & & & & & \\
\hline \multicolumn{9}{|c|}{ COEFFICIENT } \\
\hline Model & & $\beta$ & Std. Error & Beta & Sig. $(p$, & & Tolerance & VIF \\
\hline Constant & & 1.209 & 0.223 & & 0.000 & & & \\
\hline Customer sa & ction and retention & 0.134 & 0.087 & 0.158 & 0.125 & & 0.321 & 3.117 \\
\hline Market Opp & nities & 0.193 & 0.068 & 0.248 & 0.05 & & 0.439 & 2.278 \\
\hline Regular asse & ent of operations & 0.130 & 0.067 & 0.168 & 0.056 & & 0.443 & 2.259 \\
\hline Employee's & abilities & 0.098 & 0.085 & 0.105 & 0.253 & & 0.399 & 2.508 \\
\hline Increment in & enue generation & 0.230 & 0.071 & 0.274 & 0.002 & & 0.466 & 2.145 \\
\hline Efficient cha & 1 functions & 0.097 & 0.074 & 0.122 & 0.192 & & 0.388 & 2.578 \\
\hline \multicolumn{9}{|c|}{ Pearson Correlation } \\
\hline \multicolumn{2}{|c|}{ Customer satisfaction and retention } & \multicolumn{2}{|c|}{$0.627^{* * *}$} & \multicolumn{3}{|c|}{0.000} & & \\
\hline \multicolumn{2}{|c|}{ Market Opportunities } & \multicolumn{2}{|c|}{$0.614^{* * *}$} & \multicolumn{3}{|c|}{0.000} & & \\
\hline \multicolumn{2}{|c|}{ Regular assessment of operations } & \multicolumn{2}{|c|}{$0.582^{*}$ * } & \multicolumn{3}{|c|}{0.000} & & \\
\hline \multicolumn{2}{|c|}{ Employee's capabilities } & \multicolumn{2}{|c|}{$0.496^{\text {*水 }}$} & \multicolumn{3}{|c|}{0.000} & & \\
\hline \multicolumn{2}{|c|}{ Increment in revenue generation } & \multicolumn{2}{|c|}{$0.645^{\text {*** }}$} & \multicolumn{3}{|c|}{0.000} & & \\
\hline \multicolumn{2}{|c|}{ Efficient channel functions } & \multicolumn{2}{|c|}{$0.596^{* *}$} & \multicolumn{3}{|c|}{0.000} & & \\
\hline
\end{tabular}

a. Dependent Variable: Firm's performance

b. Predictors: (Constant), Efficient channel functions, Regular assessment of operations, Market Opportunities, Increment in revenue generation, Employee Capabilities, Entrepreneurship Orientation, Customer Satisfaction and Retention, Business Model Innovation.

** Correlation is significant at the 0.01 level (1-tailed).

Source: Field Report, 2021

Table 3 exhibited a statistical relationship between BMI and the performance of the selected micro and small businesses in the study location using Correlation and multiple regression analysis. The dependent variable was firm performance, and the independent variable was BMI. The Pearson Correlation coefficient was 0.683 , and the $\rho$-value was 0.000 . The Coefficient $(r)$ is high and statistically significant; thus, BMI strongly influences micro and small businesses' performance in Nigeria. The model summary results $(\mathrm{R} 2=0.466$; F-value $=122.404$; Sig. $=0.000)$ and ANOVA test $(\mathrm{F}$ value $=27.144 ; \rho<0.01$ ) of the regression analysis showed that model is significant. The value of the R2 revealed that BMI explained a 46.6 percent variance in a firm's performance. The Coefficient ( $\beta$ ) of BMI $(0.630)$ was positive and significant $(\rho<$ 0.01). This indicates that when BMI increases by $1 \%$, a firm's performance increases by 63 percent. Therefore, there is a positive and significant relationship between BMI 
and a firm's performance, and this led to the acceptance of H1, which stated that BMI had a positive and significant influence on the performance of micro and small businesses in Nigeria. This finding is in line with the findings of some of the previous studies, such as Asemokha et al. (2019), Bouncken and Fredrich (2016), Clauss et al. (2019), Dewi and Ahamat (2018), Desyllas et al. (2020), Foss and Saebi (2017), Pucihar, et al. (2019), Visnjic et al. (2016), and Smajlović et al. (2019).

Table 3: Regression Analysis Results on Effect of BMI on Firm's Performance

\begin{tabular}{|c|c|c|c|c|c|c|c|c|}
\hline \multicolumn{9}{|c|}{ MODEL SUMMARY } \\
\hline Model & $\mathrm{R}$ & \multirow{2}{*}{\multicolumn{2}{|c|}{$\begin{array}{l}\text { R Square } \\
0.466\end{array}$}} & \multirow{2}{*}{$\begin{array}{l}\text { Adjusted R Square } \\
0.463\end{array}$} & \multirow{3}{*}{$\begin{array}{l}\mathrm{F} \\
122.404\end{array}$} & \multirow{3}{*}{$\begin{array}{l}\text { Sig. } \\
0.000\end{array}$} & \multirow{2}{*}{\multicolumn{2}{|c|}{$\begin{array}{c}\text { Durbin-Watson } \\
1.708\end{array}$}} \\
\hline 1 & 0.683 & & & & & & & \\
\hline \multicolumn{7}{|l|}{$\overline{\text { ANOVA }}$} & & \\
\hline Model & Sum of Squares & $\mathrm{df}$ & \multicolumn{2}{|c|}{ Mean Square } & $\mathrm{F}$ & \multicolumn{3}{|l|}{ Sig. } \\
\hline Regression & 46.759 & 1 & 46.759 & & 27.144 & 0.000 & & \\
\hline Residual & 53.481 & 140 & 0.382 & & & & & \\
\hline Total & 100.239 & 141 & & & & & & \\
\hline \multicolumn{2}{|c|}{ COEFFICIENT } & & & & \multirow[b]{2}{*}{ g. $(p)$} & \multirow{2}{*}{\multicolumn{2}{|c|}{ Tolerance }} & \\
\hline \multicolumn{2}{|c|}{ Model } & $\beta$ & Std. Error & Beta & & & & VIF \\
\hline \multicolumn{2}{|l|}{ Constant } & 1.413 & 0.212 & & 0.000 & & & \\
\hline \multicolumn{2}{|c|}{ Business Model Innovation } & 0.630 & 0.057 & & 0.000 & & 1.000 & 1.000 \\
\hline \multirow{2}{*}{\multicolumn{2}{|c|}{$\begin{array}{l}\text { Pearson Correlation } \\
\text { Business Model Innovation }\end{array}$}} & & & & \multirow[b]{2}{*}{0.000} & & & \\
\hline & & $0.683^{*}$ & & & & & & \\
\hline
\end{tabular}

a. Dependent Variable: Firm's performance

b. Predictors: (Constant), Business Model Innovation

c. ${ }^{* *}$ Correlation is significant at the 0.01 level (1-tailed).

Source: Field Report, 2021

The statistical relationship between entrepreneurship orientation and enterprises performance was shown in Table 4. The Pearson correlation coefficient $(r=0.767)$ was positive and strong, besides, it was significant $(p<.001)$ at 1 percent. This showed a positive and significant relationship between EO and a firm's performance in the sampled MSEs. The results of the Model summary and ANOVA (R2=0.589; F-value = 200.84; Sig. $=0.000$ ) exhibited that the model was significant. EO had a positive and significant effect on firm performance $(\beta=0.716 ; p<.01)$. The $\beta$ score of 0.716 means that when EO increases by 1 percent, firm performance increases by about 72 percent. Therefore, this study hypothesis (H3) which says that EO has a significant positive relationship with firm performance, was accepted. This finding is consistent with the work of Bouncken and Fredrich (2016), Cuevas-Vargas et al. (2019), Dawi and Ahamat (2018), Dewi and Ahamat (2018), Foss and Saebi, (2017), Martens et al. (2018), Soares and Perin (2020), and Visnjic et al. (2016). 
Table 4: Regression Analysis Results on the effect of EO on Firm's Performance

\begin{tabular}{|c|c|c|c|c|c|c|c|}
\hline \multicolumn{8}{|c|}{ MODEL SUMMARY } \\
\hline Model & \multirow{2}{*}{$\begin{array}{l}\mathrm{R} \\
0.767\end{array}$} & \multicolumn{2}{|c|}{ R Square } & Adjusted R Square & $\mathrm{F}$ & \multirow{2}{*}{$\begin{array}{l}\text { Sig. } \\
0.000\end{array}$} & Durbin-Watson \\
\hline 1 & & 0.589 & 0.586 & & 200.484 & & 1.671 \\
\hline \multicolumn{8}{|l|}{ ANOVA } \\
\hline Model & Sum of Squares & df & Mean Square & \multicolumn{2}{|c|}{$\mathrm{F}$} & \multicolumn{2}{|l|}{ Sig. } \\
\hline Regression & 59.023 & 1 & 59.023 & \multicolumn{2}{|c|}{200.484} & 0.000 & \\
\hline Residual & 41.216 & 140 & 0.294 & & & & \\
\hline Total & 100.239 & 141 & & & & & \\
\hline \multicolumn{2}{|c|}{ COEFFICIENT } & & & & & & \\
\hline \multicolumn{2}{|c|}{ Model } & $\beta$ & Std. Error & Beta & Sig. $(p)$ & Tolerance & VIF \\
\hline \multicolumn{2}{|l|}{ Constant } & 1.051 & 0.191 & & 0.000 & & \\
\hline \multicolumn{2}{|c|}{ Entrepreneurship Orientation } & 0.716 & 0.051 & 0.767 & 0.000 & 1.000 & 1.000 \\
\hline \multicolumn{2}{|c|}{ Pearson Correlation } & & & & & & \\
\hline \multicolumn{2}{|c|}{ Entrepreneurship Orientation } & $0.767^{*}$ & & & 0.000 & & \\
\hline
\end{tabular}

a. Dependent Variable: Firm's performance

b. Predictors: (Constant), Entrepreneurship Orientation

** Correlation is significant at the 0.01 level (1-tailed).

Source: Field Report, 2021

The results presented in Table 5 showed a correlation between EO and BMI. The Pearson coefficient revealed a strong, positive, and significant relationship between $\mathrm{EO}$ and BMI $(\mathrm{r}=0: 838 ; \rho=0.000)$. The value of R2 is 0.702, meaning that there is a variance of 70.2 percent in BMI explained by EO. This implies that when MSEs in Nigeria make changes in their EO, it is inevitable that their performances will increase. More so, the regression results revealed that the regression model was the best fit for predicting the effect of EO on BMI ( F=200.484; $\rho=0.000)$. Also, the standardized Coefficient $(\beta=0.838 ; \rho=0.000)$ showed that every unit change in EO would significantly affect the variance in BMI by about 84 percent. This led to the acceptance of the hypothesis (H2c) that there is a significant influence of EO on BMI. This finding is in line with existing studies such as Aunalal and Aponno (2019), Asemokha et al. (2019), Bouncken et al. (2016), Ciampi et al. (2021), Danarahmanto et al. (2019), Dawi and Ahamat (2018), and Lianfeng et al. (2021). 


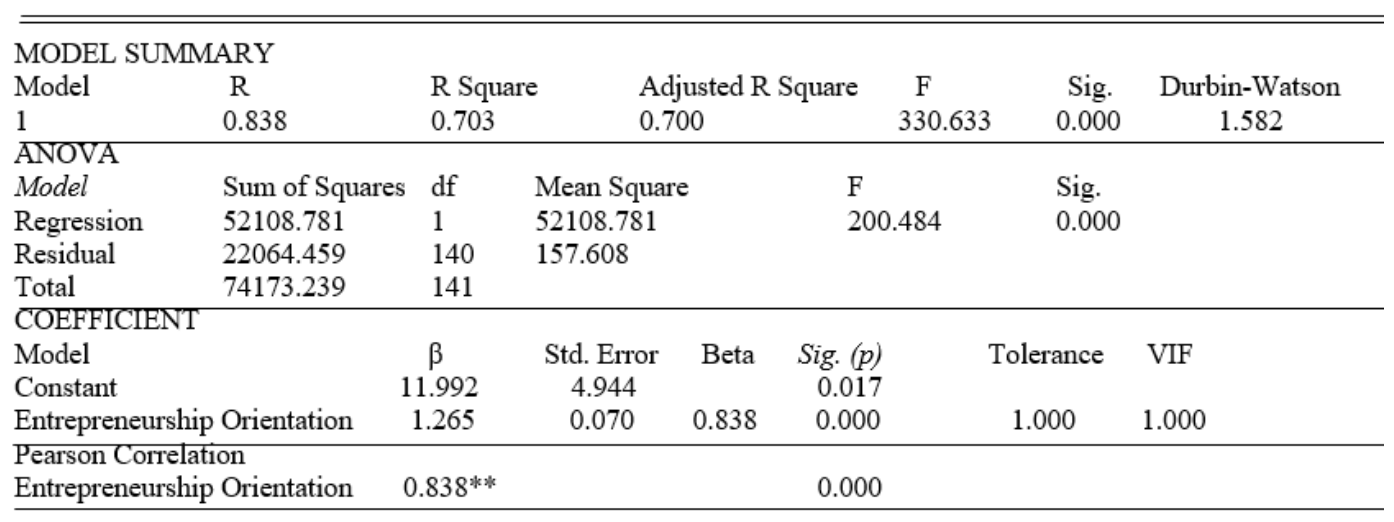

a. Dependent Variable: Business Model Innovation

b. Predictors: (Constant), Entrepreneurship Orientation

** Correlation is significant at the 0.01 level (1-tailed).

Source: Field Report, 2021

The output of the regression analysis done through PROCESS MACRO, as shown in Table 6, indicated that the difference between regression coefficients of BMI at both the total and direct effect had statistically significant values $\beta=0.3374, p<0.05$, and in addition, the product of the regression coefficients for EO at both the direct and indirect effects showed statistically significant values $(\beta=.3374, p<0.05)$. These results mean that at the introduction of $\mathrm{EO}$ as a mediating variable, the Coefficient of the BMI reduced as compared to the Coefficient of BMI when there was no mediator. Furthermore, the product of Coefficient of EO when it was introduced as a mediator and when it was regressed against BMI produced a statically significant result. Following the decision criterion given by MacKinnon, et al. (2002), that the statistical significance of mediating variable when introduced as a mediator subject to the significant value of the independent variable when mediating variable was introduced is an evidence of partial mediation effect. Therefore, this criterion is met (EO: $\beta=$ 0.5740 , BMI: $\beta=0.1281 \& p<0.05$ ), and it can be concluded that entrepreneurial orientation had a partial significant mediating effect on the relationship between Business Model Innovation and firm's performance. The findings of mediating effect of EO in the relationship between organizational events and performance-related outcomes is in tandem with previous studies of Ciampi et al. (2021), and Aunalal and Aponno (2019). 
Table 6: Regression Result for Mediating Effect of Entrepreneurial Orientation

\begin{tabular}{|c|c|c|c|c|c|}
\hline Parameter & $\begin{array}{l}\text { Step 1 } \\
\text { Total Effect }\end{array}$ & $\begin{array}{l}\text { Step } 2 \\
\text { Direct Effect }\end{array}$ & $\begin{array}{l}\text { Step } 3 \\
\text { Indirect Effect }\end{array}$ & Test & Remarks \\
\hline $\mathrm{R}$ & 0.7993 & 0.8138 & 0.8454 & \multirow{6}{*}{$\begin{array}{l}\mathrm{B}_{1}-\beta_{2}=0.3374 \\
\mathrm{~B}_{3} * \beta_{4}=0.3374\end{array}$} & \multirow{6}{*}{$\begin{array}{l}\text { There is a } \\
\text { partial } \\
\text { mediation }\end{array}$} \\
\hline $\mathrm{R}^{2}$ & 0.5466 & 0.6612 & 0.7148 & & \\
\hline F-value & 168.76 & 135.62 & 350.83 & & \\
\hline $\mathrm{Sig}(0.05)$ & 0.000 & 0.000 & 0.000 & & \\
\hline BMI & $\beta_{1}=0.4655^{\text {*** }}$ & $\mathrm{B}_{2}=0.1281^{\text {*k }}$ 水 & $\mathrm{B}_{4}=0.5879 * *$ & & \\
\hline EO & - & $\mathrm{B}_{3}=0.5740$ & 0.3374 & & \\
\hline
\end{tabular}

Note: *Coefficient is significant at 5 percent. $p<0.05\left(\beta_{1}-\beta_{2}=\beta_{3}{ }^{*} \beta_{4}\right)$.

\section{Conclusion}

The thrust of this study was to empirically investigate the influence of BMI on a firm's performance and explore the mediating role of EO between BMI and the performance of micro and small businesses in Nigeria. This research's outcomes indicated a positive and significant relationship between BMI and micro and small businesses' performance. Besides, results showed that entrepreneurship orientation and BMI are positively related, and the former mediates the relationship between the latter and the performance of micro and small businesses in Nigeria. Therefore, the adaptation of BMI by small businesses will provide an alternative platform to remain competitive and attain sustainable performance over competitors. Since it had been statistically established that BMI and EO are significant determinants of a firm's performance, we concluded that the owners/representatives and managers of micro and small businesses in developing economies, especially in sub-Saharan African countries, should integrate BMI and EO activities into their operations in order to overcome the macerate performance that characterized Covid 19 pandemic period. This study finding has answered the calls for the extension of studies on BMI and research that link other components of BMI by identifying two BMI constructs, namely, market opportunities (external factor) and increment in revenue generation (internal factor) drive firm's performance. Based on our findings, we recommended that government ministries, departments, and agencies in charge of small and medium scale enterprises development in Nigeria should facilitate the adoption of BMI by small businesses through the creation of awareness programs on innovation generally, and particularly on the enhancement of customer satisfaction and retention, identification of market opportunities, and boosting of revenue generation.

\section{Limitations and Suggestions for further study}

This study focused only on the mediating role of EO in the relationship between BMI and a firm's performance. However, the role of other mediating variables such as efficiency growth, revenue growth, and organizational capabilities on the relationship between BMI and a firm's performance has not been intensively investigated; hence, there is a need for further research on how BMI indirectly impacts a firm's performance. Also, this study only covered a state out of the thirty-six states in the 
country, which we considered to be small for generalization. Thus, we call for further elaborate research works that cut across all the six political, geographical zones in Nigeria. Besides, an attempt should be made by future research to examine the influence of BMI on a firm's performance in medium and large-scale enterprises in different sectors of the Nigerian economy. In addition, future researchers on BMI should endeavor to conduct comparative studies between two or more sectors/industries as this can provide more beneficial insights.

\section{Acknowledgment}

In preparing this study, we received valuable assistance and support from several persons to express my sincere gratitude. We especially acknowledge the contribution of our colleagues in persons of Professor A. O. Fatusin for his constructive criticisms and editorial work. Our gratitude also goes to the study research assistants, specifically Mr. Benjamin Chukwuka, for taking risks in administering and collating the study questionnaire during the Covid 19 pandemic.

\section{Funding}

The authors do not collect funding from any individual, group, and institution for this research. The authors solely sponsored the research.

\section{References}

[1] Abdel-Maksoud, A., Cheffi, W., \& Ghoudi, K. (2016). The mediating effect of shop-floor involvement on relations between advanced management accounting practices and operational non-financial performance indicators. The British Accounting Review, 48(2), 169-184. https://doi.org/10.1016/j.bar.2015.10.002

[2] Almatrooshi, B, Singh, S. K., \& Farouk, S. (2016). Determinants of organizational performance: A proposed framework. International Journal of Productivity and Performance Management, 65(6), 844-859. https://doi.org/10.1108/IJPPM-02-2016-0038.

[3] Amit, R., \& Zott, C. (2001). Value creation in e-business. Strategic Management Journal, 22(6/7), 493-520.

[4] Anderson, B. S., Kreiser, P. M., Kuratko, D. F., Hornsby, J. S., \& Eshima, Y. (2015). Reconceptualising entrepreneurial orientation. Strategic Management Journal, 36 (10), 1579-1596.

[5] Asemokha, A., Musona, J., \& Torkkeli, L. (2019). Business model innovation and entrepreneurial orientation relationships in SMEs: Implications for international performance. Journal of International Entrepreneurship, 17, 425-453. https://doi.org/10.1007/s10843-019-00254-3

[6] Aunalal, Z. I., \& Aponno, E. H. (2019). Innovation as intervening variable between entrepreneurial orientation and learning orientation with company 
performance on MSEs in Ambon City. Scientific Research Journal (Scirj), VII(IX), 11-19. DOI: 10.31364/SCIRJ/v7.i9.2019.P0919693

[7] Awan, W. A. (2013). Impact of employee orientation on retention: A case of service sector organizations in Pakistan. Interdisciplinary Journal of Contemporary Research in Business, 5(4), 326-333.

[8] Baghiu, M. C. (2020). Analysis of business model innovation in the postCovid economy: Determinants for success. Journal of Public Administration, Finance and Law, 17, 7-24

[9] Bhatti, S. H., Santoro, G., Khan, J. \& Rizzato, F. (2020). Antecedents and consequences of business model innovation in the IT industry. Journal of Business Research, 123, 389-400. https://doi.org/10.1016/j.jbusres.2020.10.003

[10] Bjorkdahl, J., \& Holmén, M. (2013). Editorial: Business model innovation The challenges ahead. International Journal of Product Development, 18(3/4), 213-225.

[11] Bouncken, R. B., Plüschke, B. D., Pesch, R., \& Kraus, S. (2016). Entrepreneurial orientation in vertical alliances: Joint product innovation and learning from allies. Review of Managerial Science 10(2), 381-409. https://doi.org/10.1007/s11846-014-0150-8.

[12] Bouwman, H., Nikou, S., Molina-Castillo, F. J., \& de Reuver, M. (2018). The impact of digitalization on business models, $D P R G, 20(2), 105-124$

[13] Bustinza, O.F., Lafuente, E., Rabetino, R., Vaillant, Y., \& VendrellHerrero, F. (2019). Make-or-buy configurational approaches in productservice ecosystems and performance. Journal of Business Research, 104, 393401.

[14] Campos, H. M., \& Valenzuela, F. A. A. (2013). The relationship between entrepreneurial orientation, time orientation and small business performance: Evidence from Mexico. Revista da Micro e Pequena Empresa, Campo Limpo Paulista, 7(1), 48-63.

[15] Campos, H. M., Nuno de la Parra, J. P., \& Parellada, F. S. (2012). The entrepreneurial orientation-dominant logic-performance relationship in new ventures: An exploratory quantitative study. BAR, Rio de Janeiro, 9(4), 60-77.

[16] China Statistical Yearbook, 2019

[17] Choudhary, A., Akhtar, S., \& Zaheer, A. (2013). Impact of transformational and servant leadership on organizational performance: A comparative analysis. Journal of Business Ethics, 116(2), 433-440. doi:10.1007/s10551012-1470-8

[18] Ciampi, F., Demi, S., \& Magrini, A. (2020). Exploring the impact of big data analytics capabilities on business model innovation: The mediating role of entrepreneurial orientation. Journal of Business Research, 123, 1-17. DOI: 10.1016/j.jbusres.2020.09.023 
[19] Clauß, T. (2017). Measuring business model innovation: Conceptualization, scale development and proof of 385-403. DOI:10.1111/radm.12186.

[20] Clauss, T., Abebe, M., Tangpong, C., \& Hock, M. (2019). Strategic agility, business model innovation, and firm performance: An empirical investigation. IEEE Transactions on Engineering Management, 99, 1-18. DOI: 10.1109/TEM.2019.2910381

[21] Covin, J. G., \& Wales, J. (2019). Crafting high-impact entrepreneurial orientation research: Some suggested guidelines. Entrepreneurship Theory and Practice, 43(1), 3-18.

[22] Covin, J. G., Eggers, F., Kraus, S., Cheng, C. F., \& Chang, M. L. (2016). Marketing-related resources and radical innovativeness in family and nonfamily firms: A configurational approach. Journal of Business Research, 69(12), 5620-5627.

[23] Cuevas-Vargas, H., Parga-Montoya, N., \& Fernández-Escobedo, R. (2019). Effects of entrepreneurial orientation on business performance: The mediating role of customer satisfaction-A formative-reflective model analysis, SAGE Open, 1-14. https://doi.org/10.1177/2158244019859088

[24] Danarahmanto, P. A., Primiana, I., Azis, Y., \& Kaltum, U. (2019). Business model innovation and entrepreneurial orientation on digital start-up sustainability in Indonesia. DLSU Business \& Economics Review 28(2), 206216.

[25] Das, S., \& Mohiuddin, K. M. (2015). Motivational factors and the constraints of women entrepreneurship development in Bangladesh. International Journal of Information, Business, and Management, 7(3), 377-396.

[26] Dekker, J., Lybaert, N., Steijvers, T., \& Depaire, B. (2015). The effect of family business professionalization as a multidimensional construct on firm performance. Journal of Small Business Management, 53(2), 516-538. https://doi.org/10.1111/jsbm.12082

[27] Department of Statistics Malaysia (DOSM), (2018)

[28] Desyllas, P., Salter, A., \& Alexy, O. (2020). The breadth of business model reconfiguration and firm performance. Strategic Organization, 1-39. https://doi.org/10.1177/1476127020955138.

[29] Dewi, S., \& Ahamat, A. (2018). The role of entrepreneurial orientation in achieving organizational performance through business model innovation and asset relational collaboration. Humanities \& Social Science Reviews, 6(2), 100-105. https://doi.org/10.18510/hssr.2018.6212

[30] Faloye, O. D. (2015). Constraints facing firms in developing countries: A survey of Nigerian small and medium scale enterprises. Research Journal of Social Science \& Management, 5(4), 188-197

[31] Faloye, O. D., Owoeye, I., \& Jayeola, K. (2021). The key drivers of business model innovation in developing countries' firms: Survey of micro and small 
scale enterprises in Nigeria. International Journal of Research and Innovation in Social Science (IJRISS), V(VII), 148-157.

[32] Filser, M., \& Eggers, F. (2013). Entrepreneurial orientation and firm performance: A comparative study of Austria, Liechtenstein, and Switzerland, South African Journal of Business Management, 45(1), 117-31. DOI: 10.4102/sajbm.v45i1.117

[33] Foss, N. J. \& Seabi, T. (2018). Business models and business model innovation: Between wicked and paradigmatic problems. Long Range Planning, DOI: 10.1016/j.lrp.2017.07.006

[34] Foss, N. J., \& Saebi, T. (2017). Fifteen years of research on business model innovation: How far have we come, and where should we go? Journal of Management, 43(1), 200-227.

[35] Fsb (2020) UK small business statistics. https://www.fsb.org.uk/uk-smallbusiness-statistics.html

[36] Fusion, A. F. (2012.) AN analysis of age and ownership structures of smallscale industrial establishments in Ondo State. European Scientific Journal, ESJ, 8, 109-117. DOI: 10.19044/ESJ.2012.V8N7P\%P

[37] Geissdoerfer, M., Vladimirova, D., \& Evans S. (2018). Sustainable business model innovation: A review. Journal of Cleaner Production, 198, 401-416. https://doi.org/10.1016/j.jclepro.2018.06.240

[38] Gherhes, C.A., Williams, N., Vorley, T. (2016). Distinguishing microbusinesses from SMEs: A systematic review of growth constraints. Journal of Small Business and Enterprise Development, 23 (4), 939-963. ISSN 1758-7840.

http://eprints.whiterose.ac.uk/106975/1/Distinguishing\%20microbusinesses\%20from\%20SMEs_AAM.PDF

[39] Gupta, V. K., \& Batra, S. (2015). Entrepreneurial orientation and firm performance in Indian SMEs: Universal and contingency perspectives. International Small Business Journal, 1- 23.

[40] Haggège, M., Gauthier, C., \& Rüling, C. C. (2017). Business model performance: Five key drivers. Journal of Business Strategy, 38(2), 6-15. https://doi.org/10.1108/JBS-09-2016-0093

[41] Hernández-Perlines, F., Moreno-García, J., \& Yañez-Araque, B. (2016). The mediating role of competitive strategy in international entrepreneurial orientation. Journal of Business Research, 69(11), 5383-5389.

[42] Hughes, M., \& Morgan, R. E. (2007). Deconstructing the relationship between entrepreneurial orientation and business performance at the embryonic stage of firm growth. Industrial Marketing Management, 36, 651-661.

[43] IFC (2010). Scaling-up SME Access to financial services in the developing world. International Finance Corporation, World Bank Group, Washington $D C$, http://www.enterprisedevelopment.org/wpcontent/uploads/ScalingUp_SM E_Access_to_ Financial_Services.pdf 
[44] International Council for Small Business (2019). Annual global micro, Small, and medium-sized enterprises report. https://icsb.org/wpcontent/uploads/2019/09/REPORT-2019.pdf

[45] Jalali, A, Jaafar, M., \& Ramayah, T. (2014). Entrepreneurial orientation and performance: The interaction effect of customer capital. World Journal of Entrepreneurship, Management and Sustainable Development, 10(1), 48-68

[46] Karimi, J., \& Walter, Z. (2016). Corporate entrepreneurship, disruptive business model innovation adoption, and its performance: The case of the newspaper industry. Long Range Planning, 49(3), 342-360. https://doi.org/10.1016/j.lrp.2015.09.004

[47] Kiyabo, K., Isaga, N. (2020). Entrepreneurial orientation, competitive advantage, and SMEs' performance: Application of firm growth and personal wealth measures. Journal of Innovation and Entrepreneurship, 9(12). https://doi.org/10.1186/s13731-020-00123-7

[48] Kurniawati, E. \& Setiawan, A. (2019). The role of Indonesian micro, small, and medium enterprises owners in choosing e-commerce strategy in the global market. Proceedings of the 1st International Conference on Social Knowledge Sciences and Education (ICSKSE 2018), 191-194.

[49] Kyllianen, J. (2019). Types of innovation: The ultimate guide with definitions and examples. Available at https://www.viima.com/blog/types-ofinnovation

[50] Laszczuk, A., \& Mayer, J. C. (2020). Unpacking business model innovation through the attention-based view. Management, 23(1): 38-60 http://dx.doi.org/10.37725/mgmt.v23.4426

[51] Latifi, M-A., \& Bouwman, H. (2018). Business model innovation and firm performance: The role of mediation and moderation factors. In Conference Proceedings of the 31st Bled eConference Digital Transformation: Meeting the Challenges: June 17 - 20, Bled, Slovenia (pp. 67-83). Maribor: University of Maribor Press. https://doi.org/10.18690/978-961-286-170-4.5

[52] Lianfeng, Z., Zhuanqing, C., \& Danko, Y. (2021). Strategic Orientation, Innovation and Entrepreneurship Model and Economic Performance - Empirical Analysis from Chinese Data. International Journal of Innovation, Creativity, and Change. 15(5), 849-469

[53] Lin, Y. H. \& Tseng, M. L. (2016). Assessing the competitive priorities within sustainable supply chain management under uncertainty. Journal of Cleaner Production, 112(1), 2133-2144. 10.1016/j.jclepro.2014.07.012

[54] Liu, K., Bian, Y., \& Yu, A. (2018). Environmental efficiency evaluation of industrial sector in China by incorporating learning. Long Range Planning, 43(2-3), https://doi.org/10.1016/j.lrp.2010. 02.004.

[55] Lomberg, C., Urbig, D., Stoeckmann, C., \& Dickson, P. H. (2017). Entrepreneurial orientation: The dimensions' shared effects in explaining 
firm performance. Entrepreneurship $\quad$ Theory, and Practice, 41(6), 973-999. DOI: $10.1111 /$ etap.12237.

[56] Lonial, S. C., \& Carter, R. E. (2015). The impact of organizational orientations on medium and small firm performance: A resource-based perspective. Journal of Small Business Management, 53(1), 94-113. https://doi.org/10.1111/jsbm.12054

[57] Madanchian, M., Hussein, N., Noordin, F., \& Taherdoos, H. (2016). The relationship between ethical leadership, leadership effectiveness and organizational performance: A review of literature in SMEs context. European Business \& Management, 2(2), 17-21. doi:10.11648/j.ebm.20160202.11

[58] Mahmood, R., \& Hanafi, N. (2013). Entrepreneurial orientation and business performance of women-owned small and medium enterprises in Malaysia: Competitive advantage as mediators. International Journal of Business and Social Science, 4(1), 82-90.

[59] Martinez, G., Renukappa, S., \& Suresh, S. (in press). Business model innovation (BMI) in small enterprises from developing countries during COVID-19 outbreak: Exploring drivers and BMI outcomes. International Journal of Business Environment. Available at https://wlv.openrepository.com/handle/2436/624043.

[60] Miller, D. (2011) Miller (1983) revisited: A reflection on EO research and some suggestions for Practice 35(5), 873-894. the future. Entrepreneurship: Theory \&

[61] Miller, D.( 1983 ) The correlates of entrepreneurial in three types of firms, Management Science, 26, 770-791.

[62] Montiel-Campos, H., \& Valenzuela, F. A. A. (2013). The relationship between entrepreneurial orientation, time orientation and small business performance: An evidence from Mexico. Revista Da Micro E Pequena Empresa, 7(1), 48-63,

[63] Mütterlein, J., \& Kunz, R. E. (2017). Innovate alone or with others? Influence of entrepreneurial orientation and alliance orientation on media business model innovation. Journal of Media Business Studies, 14(3), 173-187. https://doi.org/10.1080/16522354.2018.1445162

[64] Nassar, M. L. \& Faloye, O. D. (2015). The barrier to innovation in developing countries' firms: Evidence from Nigerian small and medium scale enterprises. European Scientific Journal, 11 (19), 196-213.

[65] OECD (2016), Entrepreneurship at a Glance. OECD Publishing, Paris.

[66] OECD (2018). Promoting innovation in established SMEs, Policy Note at SME Ministerial Conference, Mexico City

[67] Oyelana, A. A., \& Adu, E. O. (2015). Small and medium enterprises (SMEs) create employment and poverty reduction in Fort Beaufort, Eastern Cape Province of South Africa. Journal of Social Sciences, 45(1), 8-15. 
[68] Pucihar, A., Lenart, G., Borstnar, M. K., Marolt, M., \& Vidmar, D. (2019). Drivers and outcomes of business model innovation-micro, small and medium-sized enterprises perspective. Sustainability, 11(2), 344. DOI: $10.3390 /$ su 11020344

[69] Quartey, P. (2015). Issues in SME development in Ghana and South Africa. International Research Journal of Finance and Economics, 39, 218-228. https://www.researchgate.net/publication/270758190_Issues_in_SME_Dev elopment_in_ Ghana_and_South_Africa

[70] Raghuvanshi, J., Agrawal, R. \& Ghosh, P.K. (2017). Analysis of barriers to women entrepreneurship: The DEMATEL approach. Journal of Entrepreneurship, 26, 220-238.

https://doi.org/10.1177/0971355717708848

[71] Rahayu, R. \& Day, J. (2017). E-commerce adoption by SMEs in developing countries: Evidence from Indonesia, Eurasian Business Review, 7(1), 25-41. DOI:10.1007/s40821-016-0044-6.

[72] Rakesh Kumar Pati, R. K. (2018). The missing link between entrepreneurial orientation and firm performance: Business model innovation. Academy of Management, Published Online:9 July. https://doi.org/10.5465/AMBPP.2018.17588

[73] Rauter, R., Jonker, J., \& Baumgartner, R. J. (2017). Going one â€TMs way: Drivers in developing business models for sustainability. Journal of Cleaner Production, 140, 144-154.

[74] Ricarda B., Lehmann, C., \& Fellnhofer, K. (2016). The role of entrepreneurship orientation and modularity for business model innovation in service companies. International Journal of Entrepreneurial Venturing, $8(3), 237-360$.

[75] Rigtering, J. C., Kraus, S., Eggers, F., \& Jensen, S. H. (2014). A comparative analysis of the entrepreneurial orientation/growth relationship in service firms and manufacturing firms. Service Industries Journal 34(4), 275-94. https://doi.org/10.1080/02642069.2013.778978.

[76] Rigtering, J. P., Eggers, F., Kraus, S., \& Chang, M. (2017). Entrepreneurial orientation, strategic planning and firm performance: The impact of national cultures. European Journal of International Management, 11(3), 301. DOI: 10.1504/EJIM.2017.083872

[77] Saeed, S., Yousafzai, S. Y., \& Engelen, A. (2014). On cultural and macroeconomic contingencies of the entrepreneurial orientationperformance relationship. Entrepreneurship Theory and Practice, 38(2), 255290.

[78] Santos, A. \& Moustafa, G. (2016). Female entrepreneurship in developing countries - Barriers and motivation case study: Egypt and Brazil. Master of Science Thesis. KTH Industrial Engineering and Management, Stockholm. 
Retrieved from http://www.diva-portal.se/smash/get/diva2:949759/ FULLTEXT01.pdf. Accessed June 2, 2021.

[79] Selvam, M., Gayathri, J., Vasanth, V., Lingaraja, K., \& Marxiaoli, S. (2016). Determinants of firm performance: A subjective model. International Journal of Social Science Studies, 4(7), 90-100. http://dx.doi.org/10.11114/ijsss.v4i7.1662 doi:10.11114/ijsss.v4i7.1662

[80] Shepherd, D., \& Wiklund, J. (2009). Are we comparing apples with apples or apples with oranges? Appropriateness of knowledge accumulation across growth studies. Entrepreneurship Theory and Practice, 33(1), 105-123.

[81] Smajlović, S., Umihanić, B., \& Turulja, L. (2019). The interplay of technological innovation and business model innovation toward company performance. Journal of Contemporary 79. DOI: https://doi.org/10.30924/mjcmi.24.2.5

[82] Small and Medium Enterprises Development Agency of Nigeria (SMEDAN) (2007). National policy on micro, small and medium enterprises. Abuja: Federal Republic of Nigeria.

[83] Snihur, Y., \& Zott, C. (2020). The genesis and metamorphosis of novelty imprints: How business model innovation emerges in young ventures. Academy of Management Journal 63(2), 554-583. https://doi.org/10.5465/amj.2017.0706

[84] Soares, M. D. C., \& Perin, M. G. (2020). Entrepreneurial orientation and firm performance: An updated meta-analysis, RAUSP Management Journal, 55(2), 143-159. https://doi.org/10.1108/RAUSP-01-2019-0014

[85] Sriviboon, C. 2020. Strategy and performance interrelation: the mediating role of the solidarity. Journal of Security and Sustainability Issues, 9(M), 240-251. https://doi.org/10.9770/jssi.2020.9.M(19)

[86] Steinhäuser, V.P.S., Paula, F.d. \& de Macedo-Soares, T.D.L.v. (2020). Internationalization of SMEs: A systematic review of 20 years of research. Journal of International entrepreneurship. https://link.springer.com/article/10.1007/s10843-020-00271-7\#citeas

[87] Stoian, M. C., Dimitratos, P., \& Plakoyiannaki, E. (2018). SME internationalization beyond exporting: A knowledge-based perspective across managers and advisers. Journal of World Business, 53(5), 768-779. https://www.sciencedirect.com/science/article/abs/pii/S10909516173069 10

[88] Tambunan, T. (2019). Recent evidence of the development of micro, small and medium enterprises in Indonesia. Journal of Global Entrepreneurship Research, 9(18), 1-15 https://doi.org/10.1186/s40497-018-0140-4.

[89] Tambunan, T. T. H. (2018). MSMEs and access to financing in a developing economy: The Indonesian experience. In A. Woldie \& B. Thomas (Eds.), Financial entrepreneurship for economic growth in emerging nations IGI Global. 
[90] Tavassoli, S., \& Bengtsson, l. (2018). The role of business model innovation for product innovation performance. International Journal of Innovation Management, 22,(07), https://doi.org/10.1142/S1363919618500615

[91] Terjesen, S., Hessels, J., \& Li, D. (2016). Comparative international entrepreneurship: A review and research agenda. Journal of Management, 20(10), 1-46. https://journals.sagepub.com/doi/abs/10.1177/0149206313486259

[92] Tsai, K. H., \& Yang, S. Y. (2013). Firm innovativeness and business performance: The joint moderating effects of market turbulence and competition. Industrial Marketing Management, 42(8), 1279-1294. http://dx.doi.org/10.1016/j.indmarman.2013.06.001

[93] Wales, W. J. (2015). Entrepreneurial orientation: A review and synthesis of promising research direction. International Small Business Journal, 34(1), 315.

[94] Wang, Y. (2017). What are the biggest obstacles to the growth of SMEs in developing countries? An empirical evidence from an enterprise survey. Borsa Istanbul Review, 16(3), 167-176

[95] Wikipedia Org. (2014). Skunk works. Retrieved from http://en.wikipedia.org/wiki/Skunk_Works

[96] Yoshino, N. \& Farhad, T. H. (2016). Major challenges facing small and medium-sized enterprises in Asia and solutions for mitigating them. ADBI Working Paper 564, Available at SSRN: https://ssrn.com/abstract=2766242 or http://dx.doi.org/10.2139/ss rn.2766242

[97] Zafar, A. \& Mustafa, S. (2017). SMEs and their Role in economic and socioeconomic development of Pakistan. International Journal of Academic Research in Accounting, Finance and Management Sciences, 7(4), 195-205. DOI: 10.6007/IJARAFMS/v7- i4/3484 